\title{
Coseismic slip distribution of the 1946 Nankai earthquake and aseismic slips caused by the earthquake
}

\author{
Yuichiro Tanioka ${ }^{1}$ and Kenji Satake ${ }^{2}$ \\ ${ }^{1}$ Meteorological Research Institute, 1-1 Nagamine, Tsukuba 305-0052, Japan \\ ${ }^{2}$ Geological Survey of Japan, 1-1-3 Higashi, Tsukuba 305-8567, Japan \\ (Received July 26, 1999; Revised April 12, 2000; Accepted May 29, 2000)
}

\begin{abstract}
Coseismic slip distribution on the fault plane of the 1946 Nankai earthquake $\left(M_{w} 8.3\right)$ was estimated from inversion of tsunami waveforms. The following three improvements from the previous study (Satake, 1993) were made. (1) Larger number of smaller subfaults is used; (2) the subfaults fit better to the slab geometry; and (3) more detailed bathymetry data are used. The inversion result shows that the agreement between observed and synthetic waveforms is greatly improved from the previous study. In the western half of the source region off Shikoku, a large slip of about $6 \mathrm{~m}$ occurred near the down-dip end of the locked zone. The slip on the up-dip or shallow part was very small, indicating a weak seismic coupling in that region. In the eastern half of the source region off Kii peninsula, a large slip of about $3 \mathrm{~m}$ extended over the entire locked zone. Large slips on the splay faults in the upper plate estimated from geodetic data (Sagiya and Thatcher, 1999) were not required to explain the tsunami waveforms, suggesting that the large slips were aseismic. Two slip distributions on the down-dip end of the plate interface, one from geodetic data and the other from tsunami waveforms, agree well except for slip beneath Cape Muroto in Shikoku. This suggests that aseismic slip also occurred on the plate interface beneath Cape Muroto.
\end{abstract}

\section{Introduction}

Great interplate earthquakes have repeatedly occurred along the Nankai trough with an interval of about 120 years (Ishibashi and Satake, 1998). In order to prepare for the next earthquake, estimation of coseismic slip distribution on the fault plane is important because the strong motion and damage are significantly influenced by the slip distribution.

The most recent events along the Nankai trough were the 1944 Tonankai and 1946 Nankai earthquakes. In this paper, we concentrate on the 1946 Nankai earthquake. Various instrumental data have been used to study the earthquake. Kanamori (1972) studied seismological data to estimate the focal mechanism and seismic moment $\left(M_{w} 8.2\right)$. He determined the source region off Kii peninsula (Fig. 1) from the one-day aftershock distribution. Also, he suggested that the land deformation to the west of the one-day aftershock area was associated with a creep-like deformation. Fitch and Scholz (1971) and Ando (1975) used geodetic data to estimate the fault parameters. They claimed that the fault extended to off Shikoku, much further west than the aftershock area. However, their models with a small number of fault elements are so simple that the models do not explain the geodetic data very well. More detailed studies using the coseismic crustal deformation (Yabuki and Matsuura, 1992; Sagiya and Thatcher, 1999) estimated the heterogeneous slip distribution on the down-dip side of the fault plane. These studies also revealed that the crustal deformation data did not have sufficient resolution to estimate the slips on the up-dip

Copy right (C) The Society of Geomagnetism and Earth, Planetary and Space Sciences (SGEPSS); The Seismological Society of Japan; The Volcanological Society of Japan; The Geodetic Society of Japan; The Japanese Society for Planetary Sciences. (offshore) side of the fault plane.

Tsunamis from the 1946 Nankai earthquake were recorded on many tide gauge stations. Aida (1981) and Ando (1982) studied the fault parameters using three tsunami waveforms near the epicenter. Satake (1993) used a more complete data set, seven tsunami waveforms, to study the slip distribution of the earthquake. He found that slip on the trench side of the fault plane was well resolved using a tsunami waveform inversion. However, Satake (1993) did not make full use of information contained in the data, and the model did not fit the data well. The variance reduction for the tsunami inversion was only $45 \%$.

In this study, we perform tsunami waveform inversion using a method similar to that used by Satake (1993). The following improvements are made to estimate the detailed slip distribution that better explains the observed tsunami waveforms. (1) The source area in the plate interface was divided into 29 subfaults to better resolve the slip distribution; (2) the locations and dip angles of subfaults are varied to better fit the slab geometry; and (3) detailed bathymetry data from recent multibeam surveys (provided by Japan Oceanographic Data Center) were used to accurately compute the tsunami propagation.

The estimated slip distribution is compared with the locked and transition zones of the plate interface near the Nankai trough determined from other studies. Hyndman et al. (1995) indicate that the temperature profile on the plate interface controls the position of the locked zone and transition zone near the Nankai trough (Fig. 1). The estimated slip distribution is also compared with the result obtained by Sagiya and Thatcher (1999) using geodetic data. The geodetic survey 


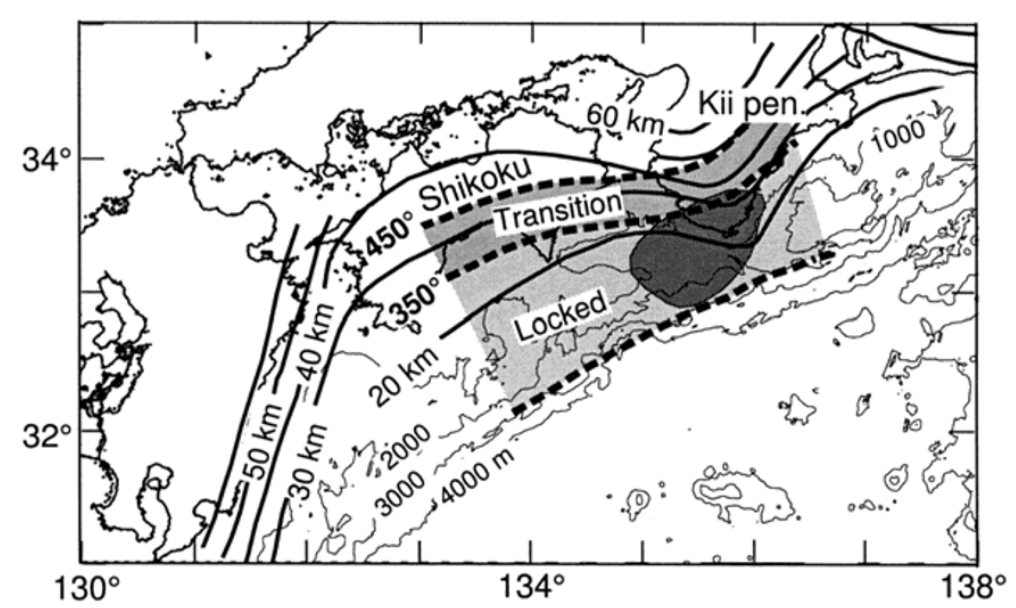

Fig. 1. Map of the plate interface near the source region of the 1946 Nankai earthquake. The upper surface of the subducted Philippine Sea plate estimated from microearthquake distribution (Mizoue et al., 1983; Okano et al., 1985; Yamazaki and Ooida, 1985; Ito, 1990) is shown by solid lines. The locked and transition zones (lighter shaded areas) with the temperature of the plate interface (dashed lines) estimated by Hyndman et al. (1995) are shown. Dark shaded area shows the one day aftershock area obtained by Kanamori (1972). Sea depth is indicated by thin contours.

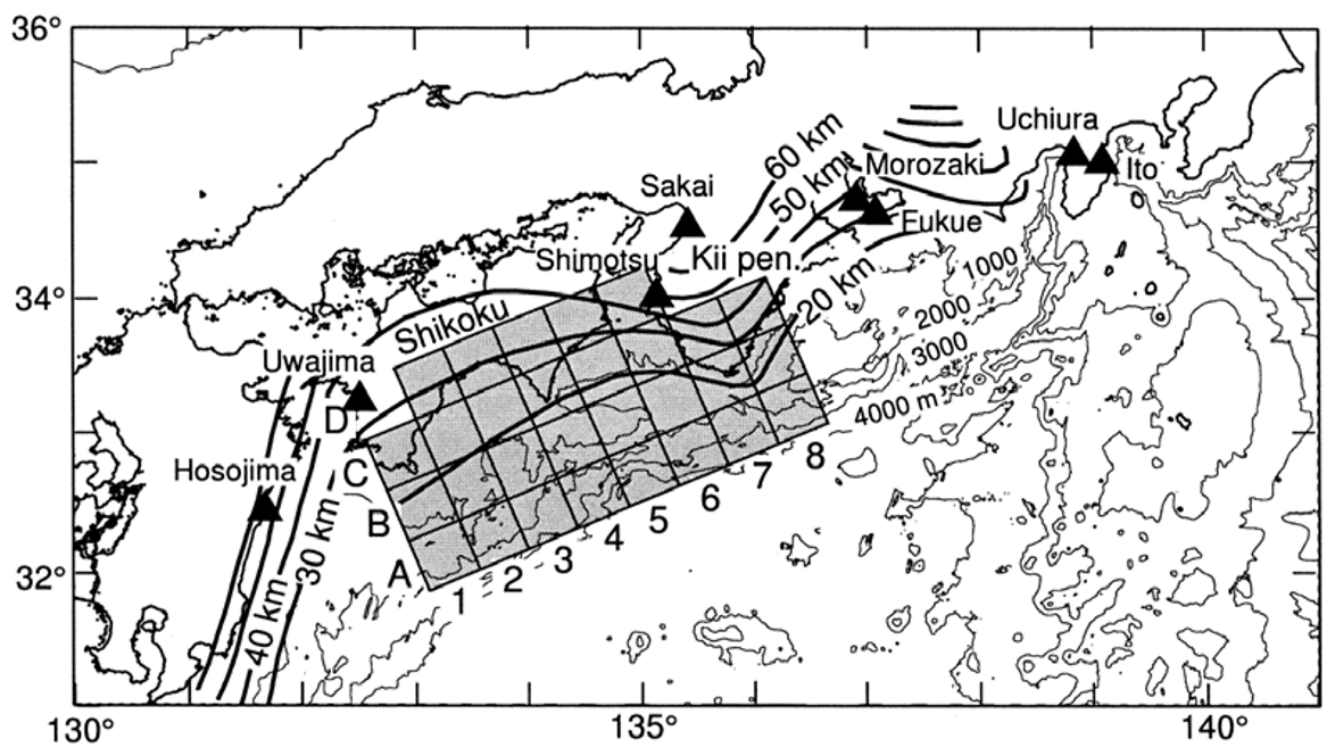

Fig. 2. The area of the tsunami computation, locations of subfaults (shaded rectangles), and tide gauges (solid triangles). Solid lines show the upper surface of the slab, the same as those in Fig. 1.

after the 1946 Nankai earthquake was completed in 1950. If there was a large aseismic (postseismic or preseismic) slip between 1946 and 1950, a large part of the aseismic slip should be included in the slip distribution estimated by Sagiya and Thatcher (1999). On the other hand, the slip distribution estimated from the tsunami waveforms should have little influence from such an aseismic slip. By comparing two slip distributions, we can investigate whether there was a large aseismic slip.

\section{Data and Method}

The depth of the upper surface of the seismogenic layer of the Philippine Sea slab was estimated from the distribution of microearthquakes (Mizoue et al., 1983; Okano et al., 1985; Yamazaki and Ooida, 1985; Ito, 1990) and is shown in Figs. 1 and 2. The slab dips steeply beneath Kii peninsula, reaching the depth of $80 \mathrm{~km}$ at a distance of $200 \mathrm{~km}$ from the trough axis, while the dip is gentler beneath Shikoku, reaching only $40 \mathrm{~km}$ depth at the same distance from the trough axis. We divided the fault into subfaults that are located on the estimated upper surface of the slab by varying the depth and dip angle (Fig. 2 and Table 1). The subfault size is 45 $\mathrm{km} \times 45 \mathrm{~km}$, the strike is $250^{\circ}$ and the rake angle is $120^{\circ}$ for all the subfaults. The strike and rake angle are the same as those used by Satake (1993).

We used tsunami waveform data recorded at eight tide gauge stations shown in Fig. 2. A tsunami waveform at Morozaki was added to the seven tsunami waveforms used by Satake (1993). The tsunami waveforms for each tide gauge station consist of 50 to 120 minutes of data points with an interval of 1 minute. The tsunami Green's functions are numerically computed on actual bathymetry. The 
Table 1. Subfaults and slip distribution.

\begin{tabular}{|c|c|c|c|c|}
\hline subfault & $\begin{array}{c}\text { depth of top edge } \\
(\mathrm{km})\end{array}$ & $\begin{array}{l}\text { dip angle } \\
\text { (degree) }\end{array}$ & $\begin{array}{l}\text { slip } \\
\text { (m) }\end{array}$ & $\begin{array}{l}\text { std error } \\
\text { (m) }\end{array}$ \\
\hline $1 \mathrm{~A}$ & 6 & 8 & 0.30 & 0.08 \\
\hline $2 \mathrm{~A}$ & 6 & 8 & 1.64 & 0.28 \\
\hline $3 \mathrm{~A}$ & 3 & 9 & 0.00 & 0.00 \\
\hline $4 \mathrm{~A}$ & 3 & 9 & 0.46 & 0.24 \\
\hline $5 \mathrm{~A}$ & 1 & 9 & 0.78 & 0.19 \\
\hline $6 \mathrm{~A}$ & 1 & 9 & 2.99 & 0.17 \\
\hline $7 \mathrm{~A}$ & 2 & 12 & 3.63 & 0.19 \\
\hline $8 \mathrm{~A}$ & 3 & 12 & 0.85 & 0.12 \\
\hline $1 \mathrm{~B}$ & 13 & 8 & 1.40 & 0.10 \\
\hline $2 \mathrm{~B}$ & 13 & 8 & 0.00 & 0.08 \\
\hline $3 B$ & 11 & 9 & 0.00 & 0.17 \\
\hline $4 B$ & 11 & 9 & 1.22 & 0.22 \\
\hline $5 B$ & 10 & 9 & 1.83 & 0.15 \\
\hline $6 \mathrm{~B}$ & 9 & 9 & 2.97 & 0.13 \\
\hline $7 \mathrm{~B}$ & 13 & 16 & 3.44 & 0.14 \\
\hline $8 \mathrm{~B}$ & 14 & 17 & 0.00 & 0.14 \\
\hline $1 \mathrm{C}$ & 20 & 9 & 1.99 & 0.05 \\
\hline $2 \mathrm{C}$ & 20 & 9 & 5.60 & 0.23 \\
\hline $3 \mathrm{C}$ & 19 & 10 & 5.34 & 0.26 \\
\hline $4 \mathrm{C}$ & 19 & 10 & 2.75 & 0.08 \\
\hline $5 \mathrm{C}$ & 17 & 13 & 6.22 & 0.15 \\
\hline $6 \mathrm{C}$ & 18 & 16 & 0.25 & 0.10 \\
\hline $7 \mathrm{C}$ & 26 & 24 & 2.91 & 0.25 \\
\hline $8 \mathrm{C}$ & 28 & 23 & 0.00 & 0.05 \\
\hline $2 \mathrm{D}$ & 27 & 9 & 2.69 & 0.23 \\
\hline $3 \mathrm{D}$ & 27 & 10 & 1.79 & 0.40 \\
\hline $4 \mathrm{D}$ & 27 & 10 & 0.00 & 0.00 \\
\hline $5 \mathrm{D}$ & 29 & 15 & 0.44 & 0.06 \\
\hline $6 \mathrm{D}$ & 31 & 26 & 0.92 & 0.07 \\
\hline
\end{tabular}

finite difference computations for the linear long-wave (see Satake, 1995) were carried out in the area shown in Fig. 2. The grid size is basically $20 \mathrm{sec}$ of arc (about $600 \mathrm{~m}$ ), but finer grids $(4 \mathrm{sec})$ were used around the tide gauge stations. The computation was made every $1.5 \mathrm{~s}$ to satisfy a stability condition. The initial condition of tsunami propagation is an ocean bottom deformation, which was computed using the equations of Okada (1985). The duration of the faulting is assumed to be 1 minute, a typical duration for an earthquake of which the magnitude is about 8. Ando (1982) suggested that the rise time of the 1946 Nankai earthquake was short enough to generate short-period seismic waves from both the western and eastern fault segments.

The waveforms at the stations were computed from each subfault with a unit amount of slip, and used as the Green's function for the inversion. The method of tsunami waveform inversion is basically the same as that of Satake (1993). The only difference is that positivity constraints are assigned for the slip estimates. For error analysis, the jackknife technique (Tichelaar and Ruff, 1989) was applied. We reinverted the tsunami waveform data twenty times, each time randomly dropping 100 data points out of 638 data points. The errors are simply the standard errors multiplied by a scale factor, $K$ (see equation (5) in the paper by Tichelaar and Ruff (1989)), defined as

$$
K=\sqrt{(n-d+m+1) / d}
$$

where $n$ is the number of data points, $d$ is the number of dropped data points, $m$ is the number of model parameters which is the number of subfaults in this study. The scale factor, $K$, is 2.38 in the present case.

\section{Slip Distribution on the Plate Interface}

The result of the inversion is shown in Fig. 3 and Table 1. The large $(>3 \mathrm{~m})$ slip is estimated on three subfaults beneath Shikoku (2C, 3C, 5C) and two subfaults off Kii peninsula (7A and $7 \mathrm{~B})$. The three subfaults beneath Shikoku align parallel to the trough axis while the two subfaults off Kii peninsula align in the down-dip direction. The largest slip was about $6 \mathrm{~m}$ on subfault $5 \mathrm{C}$. The coseismic slip on the shallow subfaults off Shikoku was very small. The errors associated with the estimation are generally small $(<0.3 \mathrm{~m})$ and uniformly distributed except on subfault $3 \mathrm{D}$. The seismic moment is calculated as $5.3 \times 10^{21} \mathrm{Nm}\left(M_{w} 8.4\right)$ assuming that the rigidity is $5 \times 10^{10} \mathrm{~N} / \mathrm{m}^{2}$. This seismic moment is slightly larger than that of Satake (1993), $3.9 \times 10^{21} \mathrm{Nm}$, but similar to that of Ando (1982), $4.7 \times 10^{21} \mathrm{Nm}$. The observed and computed tsunami waveforms are compared in Fig. 4. The agreement is much better than Satake (1993). The RMS residual is $12.8 \mathrm{~cm}$, and the variance reduction is $81 \%$, much larger than $45 \%$ obtained by Satake (1993). We believe that the large improvement of the fit between observed and synthetic waveforms was mainly obtained by using smaller subfaults that produced shorter period tsunami than the subfaults used by Satake (1993). In order to compute the shorter period tsunami accurately, the finer grid bathymetry data are necessary to avoid a large discretization error. Hence, the detailed bathymetry data from recent multibeam surveys (provided by Japan Oceanographic Data Center) was essential to the accurate tsunami computation.

\section{Discussion}

\subsection{Slip distribution and locked zone}

Hyndman et al. (1995) estimated the temperature profile on the plate interface along the Nankai trough from heat flow data. They suggested that the down-dip limits of the locked zone and transition zone were defined by the $350^{\circ} \mathrm{C}$ and $450^{\circ} \mathrm{C}$ temperature, respectively. The location of the $350^{\circ} \mathrm{C}$ and $450^{\circ} \mathrm{C}$ thermal limits are compared with the coseismic slip distribution estimated in this study in Fig. 3. In general, large slip ( $>3 \mathrm{~m}$ ) occurred near the down-dip end of the locked zone. Near Shikoku, the large slip was concentrated on the down-dip end of the locked zone. On the other hand, near Kii peninsula, the large slip extends through the entire locked zone from the down-dip end to the trough axis. This indicates that the seismic coupling in the shallow part of the locked zone near Shikoku is much weaker than that in the down-dip end of the locked zone. 

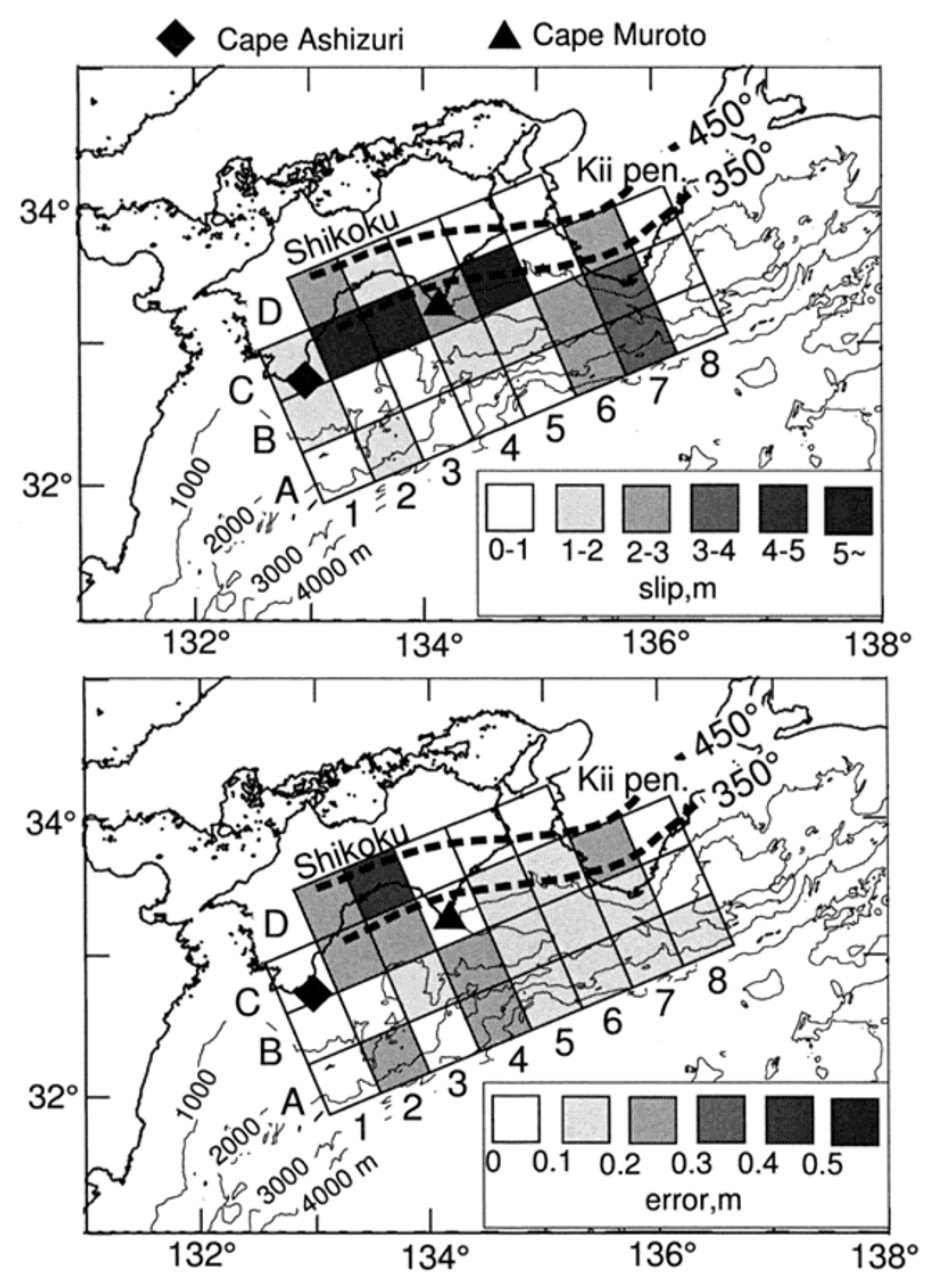

Fig. 3. Coseismic slip distribution (top) and estimated error (below) from the inversion of tsunami waveforms. Dashed lines show the temperature of the plate interface that defines the down-dip limit of the locked and transition zones (Hyndman et al., 1995).

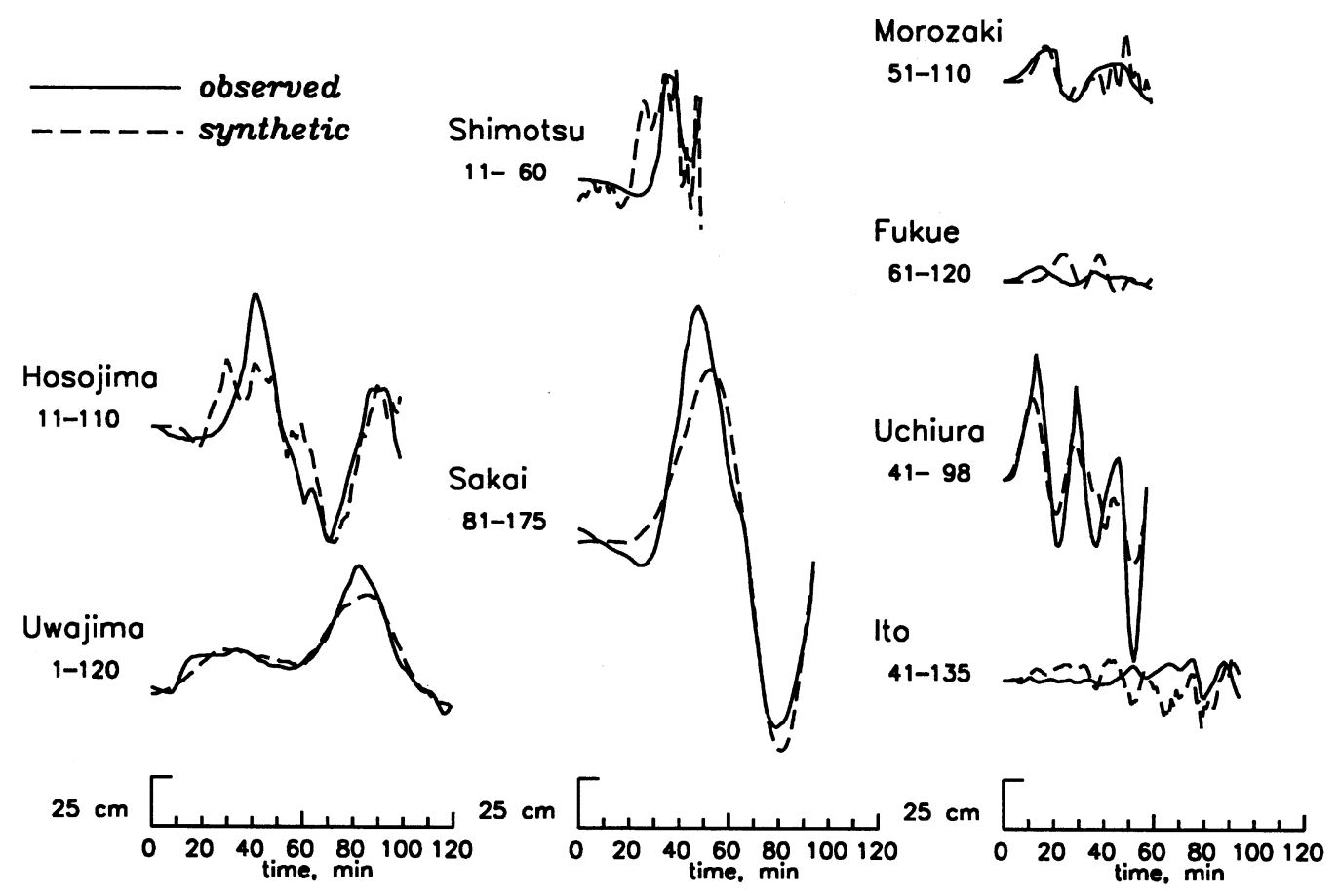

Fig. 4. Comparison of the observed (solid) and computed (dashed) tsunami waveforms at tide gauges. See Fig. 2 for the tide gauge locations. Numbers below the station name indicate the time (in minutes) after the earthquake origin time. 
Table 2. Two splay subfaults and slip distribution.

\begin{tabular}{ccccccccc}
\hline subfault & $\begin{array}{c}\text { depth } \\
(\mathrm{km})\end{array}$ & $\begin{array}{c}\text { width } \\
(\mathrm{km})\end{array}$ & $\begin{array}{c}\text { length } \\
(\mathrm{km})\end{array}$ & $\begin{array}{c}\text { strike } \\
(\text { degree })\end{array}$ & $\begin{array}{c}\text { dip } \\
(\text { degree })\end{array}$ & $\begin{array}{c}\text { rake } \\
(\text { degree })\end{array}$ & $\begin{array}{c}\text { slip } \\
(\mathrm{m})\end{array}$ & $\begin{array}{c}\text { error } \\
(\mathrm{m})\end{array}$ \\
\hline S1 & 0.0 & 13.0 & 54.4 & 216.6 & 70.0 & 114.5 & 0.25 & 0.19 \\
S2 & 0.0 & 40.0 & 104.7 & 257.9 & 30.0 & 140.0 & 0.47 & 0.16 \\
\hline
\end{tabular}

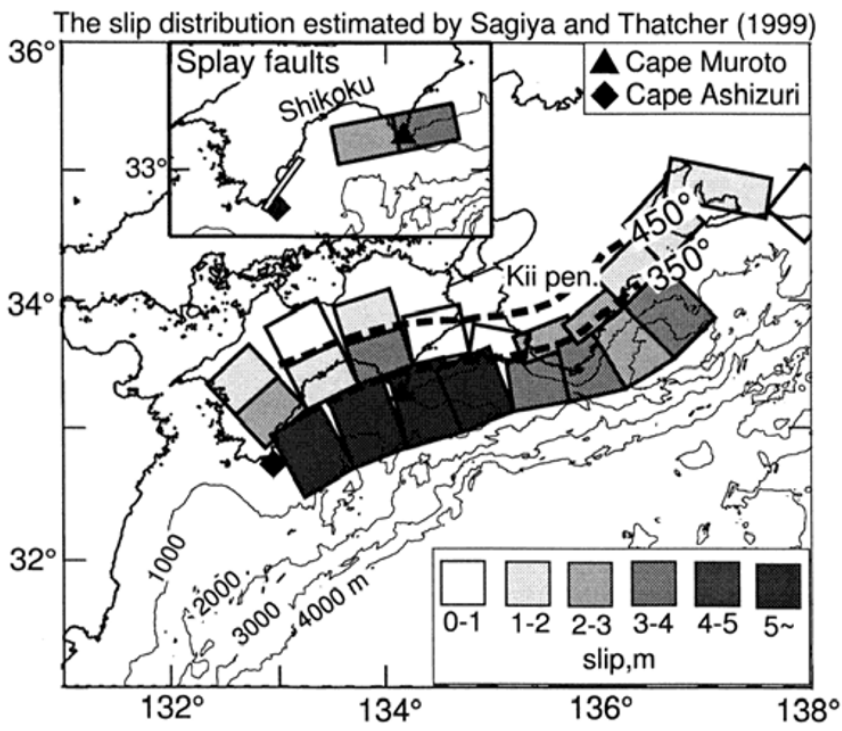

Fig. 5. The slip distribution estimated by Sagiya and Thatcher (1999) using geodetic data. Only subfaults that were well resolved to obtain the slip are shown. The inset map shows the slip estimated by Sagiya and Thatcher (1999) on three splay subfaults in the upper plate. Dashed lines are the same as those in Fig. 3.

\subsection{Comparison with the geodetic model}

Sagiya and Thatcher (1999) estimated the slip distribution and its resolution for 1944 and 1946 earthquakes from geodetic data. They could not separate the 1946 slip from the 1944 slip because no geodetic survey was done between the two events. Sagiya and Thatcher (1999) also estimated the rake angle distribution which we could not estimate using the tsunami waveforms. It is difficult to estimate a rake angle of subfaults using tsunami waveforms because, unlike geodetic data, the tsunamis do not have any information on the horizontal coseismic deformation. Figure 5 shows the slip distribution only on the subfaults that were well resolved by the geodetic data (Sagiya and Thatcher, 1999). Their subfault system has three splay faults, one near Cape Ashizuri and the other two near Cape Muroto, located in the upper plate, not on the plate interface (Fig. 5). The estimated slip on the splay subfault near Cape Ashizuri was $1.7 \mathrm{~m}$. The estimated slip on two splay subfaults near Cape Muroto was $3.2 \mathrm{~m}$ and $2.7 \mathrm{~m}$. If the slip on the splay subfaults were coseismic, they should affect the tsunami generation as well.

We added two splay faults in our subfault system, one near Ashizuri and one near Muroto, and reinverted the tsunami waveforms to find out whether these splay faults slipped coseismically (Fig. 6). The fault parameters of two splay subfaults are shown in Table 2. One large splay subfault is used near Muroto, although Sagiya and Thatcher (1999) divided

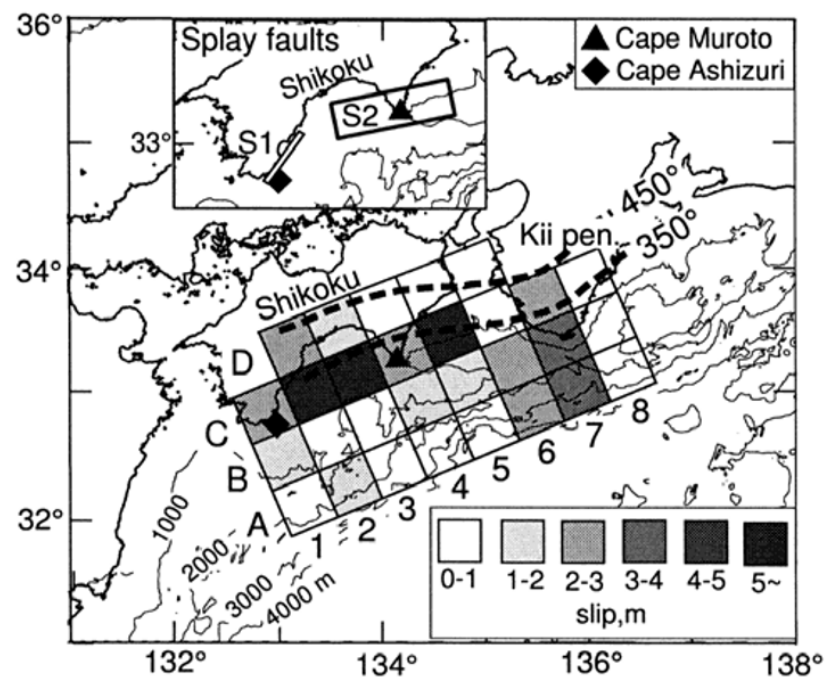

Fig. 6. Coseismic slip distribution estimated on thirty one subfaults which include two splay faults in the upper plate from the tsunami waveforms. The inset map shows the slips estimated on the splay faults. Dashed lines are the same as those in Figs. 3 and 5.

it into two. The fault parameters of the splay subfault near Ashizuri are the same as that used by Sagiya and Thatcher (1999). The estimated slip distribution is shown in Fig. 6. The estimated slip on the two splay subfaults is less than $0.5 \mathrm{~m}$, much smaller than those estimated from geodetic data. The slip distribution on the plate interface is essentially the same as the previous result in Fig. 3. This indicates that the tsunami was caused by slip on the plate interface, not on the splay subfaults. We therefore conclude that most of the slip on the splay faults estimated using geodetic data was probably aseismic (creep-like) and occurred either just before or after the 1946 earthquake and did not efficiently generate a tsunami.

We compare the slip distribution on the plate interface estimated from tsunami waveforms (Figs. 3 or 6) with that from geodetic data (Fig. 5) by Sagiya and Thatcher (1999). To the east of Kii peninsula, large slip was estimated from geodetic data, but no slip was estimated from tsunami waveforms. The large slip from geodetic data should be caused by the 1944 Tonankai earthquake, not by the 1946 Nankai earthquake. Hence, the slip to the east of the Kii peninsula is ignored in this study. The slip distributions obtained from geodetic and tsunami data are similar to each other and show large slip of about $6 \mathrm{~m}$ off Shikoku and about $3 \mathrm{~m}$ off Kii peninsula along the down-dip edge of the locked zone. However, if we carefully examine the two slip distributions, a difference between two estimates can be found near Cape Muroto. The estimated slip beneath Cape Muroto from tsunami waveforms 
Table 3. Slip distributions using three rise times.

\begin{tabular}{|c|c|c|c|}
\hline \multirow[b]{2}{*}{ subfault } & \multicolumn{3}{|c|}{ rise time } \\
\hline & $\begin{array}{l}1 \text { minute } \\
\text { slip (m) }\end{array}$ & $\begin{array}{c}3 \text { minutes } \\
\text { slip (m) }\end{array}$ & $\begin{array}{c}5 \text { minutes } \\
\text { slip (m) }\end{array}$ \\
\hline $1 \mathrm{~A}$ & 0.30 & 0.00 & 0.00 \\
\hline $2 \mathrm{~A}$ & 1.64 & 2.29 & 2.74 \\
\hline $3 \mathrm{~A}$ & 0.00 & 0.00 & 0.00 \\
\hline $4 \mathrm{~A}$ & 0.46 & 0.00 & 0.00 \\
\hline $5 \mathrm{~A}$ & 0.78 & 0.35 & 0.00 \\
\hline $6 \mathrm{~A}$ & 2.99 & 3.48 & 2.90 \\
\hline $7 \mathrm{~A}$ & 3.63 & 3.76 & 3.85 \\
\hline $8 \mathrm{~A}$ & 0.85 & 0.86 & 0.73 \\
\hline $1 \mathrm{~B}$ & 1.40 & 1.40 & 1.76 \\
\hline $2 \mathrm{~B}$ & 0.00 & 0.00 & 0.00 \\
\hline $3 \mathrm{~B}$ & 0.00 & 0.00 & 2.08 \\
\hline $4 \mathrm{~B}$ & 1.22 & 1.42 & 0.00 \\
\hline $5 \mathrm{~B}$ & 1.83 & 1.49 & 1.05 \\
\hline $6 \mathrm{~B}$ & 2.97 & 3.21 & 3.11 \\
\hline $7 \mathrm{~B}$ & 3.44 & 3.17 & 3.20 \\
\hline $8 \mathrm{~B}$ & 0.00 & 0.00 & 0.00 \\
\hline $1 \mathrm{C}$ & 1.99 & 2.46 & 1.39 \\
\hline $2 \mathrm{C}$ & 5.60 & 5.86 & 7.89 \\
\hline $3 \mathrm{C}$ & 5.34 & 5.23 & 3.34 \\
\hline $4 \mathrm{C}$ & 2.75 & 3.05 & 3.66 \\
\hline $5 \mathrm{C}$ & 6.22 & 6.15 & 5.27 \\
\hline $6 \mathrm{C}$ & 0.25 & 0.40 & 0.78 \\
\hline $7 \mathrm{C}$ & 2.91 & 3.93 & 3.50 \\
\hline $8 \mathrm{C}$ & 0.00 & 0.00 & 0.00 \\
\hline $2 \mathrm{D}$ & 2.69 & 2.07 & 0.29 \\
\hline $3 \mathrm{D}$ & 1.79 & 1.33 & 0.25 \\
\hline $4 \mathrm{D}$ & 0.00 & 0.00 & 0.00 \\
\hline $5 \mathrm{D}$ & 0.44 & 0.52 & 0.60 \\
\hline $6 \mathrm{D}$ & 0.92 & 1.25 & 1.17 \\
\hline RMS residual & $12.8 \mathrm{~cm}$ & $13.0 \mathrm{~cm}$ & $13.2 \mathrm{~cm}$ \\
\hline
\end{tabular}

is $2.7 \mathrm{~m}$, that is about half of the estimated slip, $6 \mathrm{~m}$, from geodetic data (Sagiya and Thatcher, 1999). In the transition zone, the area between $350^{\circ} \mathrm{C}$ and $450^{\circ} \mathrm{C}$ thermal limits in Figs. 3, 5, and 6, the slip distribution estimated from tsunami waveforms is also similar to the slip estimated from geodetic data except that to the north of Cape Muroto. North of Cape Muroto, the estimated slip from tsunami waveforms is less than $1 \mathrm{~m}$, much smaller than the estimated slip of $4 \mathrm{~m}$ from geodetic data. These results indicate that a large aseismic slip probably occur on the plate interface near Cape Muroto after the 1946 Nankai earthquake and before the geodetic survey, but not at other places in the plate interface. A recent example of this type of an aseismic slip is the large slip which followed the large 1994 Sanriku-oki earthquake estimated using continuous GPS observation by Heki et al. (1997).

\subsection{Rise time in the western half of the source area}

Ando (1982) suggested that the rise time of the 1946 Nankai earthquake was short enough to generate short-period seismic waves from both the western and eastern fault segments. Hence, we assume that the duration of the faulting is 1 minute, a typical duration for an earthquake of which the magnitude is about 8 . However, the fault area estimated using geodetic data (Yabuki and Matsuura, 1992; Sagiya and Thatcher, 1999) or tsunami data (this study) extends much farther west than the aftershock zone estimated by Kanamori (1972) (Fig. 1). This may suggest that the rise time of the faulting in the western part was somewhat larger than that in the eastern part.

In order to test the effect of rise time, we re-computed the tsunami waveforms using two longer rise times, 3 and 5 minutes, for 15 subfaults, 1A, 1B, 1C, 2A, 2B, 2C, 2D, 3A, 3B, 3C, 3D, 4A, 4B, 4C, and 4D in Fig. 2. Those subfaults are located in the western half of the source area. The tsunami waveforms from the other subfaults in the eastern half of the source area are the same as before. Using those tsunami waveforms as the Green's functions, we carried out the inversion to obtain the slip on the subfaults. The results are shown in Table 3. The slip distribution estimated by using the rise time of 3 minutes is essentially the same as that estimated by using the rise time of 1 minute. The RMS residual for the rise time of 3 minutes is slightly larger than that for the rise time of 1 minute, but the difference is not significant. The slip distribution estimated by using the rise time of 5 minutes is also similar to that estimated for the rise time of 1 minute. However, the difference may be significant at subfault $2 \mathrm{C}$ where the slip of $7.89 \mathrm{~m}$ was estimated for the rise time of 5 minutes although the slip of only $5.60 \mathrm{~m}$ was estimated for the rise time of 1 minute. Sagiya and Thatcher (1999) also estimated slip of about $6 \mathrm{~m}$ (Fig. 5) at the same location as subfault $2 \mathrm{C}$. Therefore, the large estimated slip at subfault $2 \mathrm{C}$ indicates that the rise time of 5 minutes may be too long. The RMS residual for the rise time of 5 minutes is also slightly larger than that for the rise time of 1 or 3 minutes. We conclude that the slip distribution estimated in this study is very stable up to the rise time of 3 minutes.

\section{Conclusion}

The slip distribution of the 1946 Nankai earthquake estimated from tsunami waveforms shows that a slip maximum of $6 \mathrm{~m}$ occurred on the down-dip end of the locked zone off Shikoku while another maximum of $3 \mathrm{~m}$ extended the entire locked zone off Kii peninsula. This indicates weak seismic coupling in the shallow part of the plate interface off Shikoku. The agreement between the observed and synthetic tsunami waveforms greatly improved from that obtained by Satake (1993). Sagiya and Thatcher (1999) estimated the large slip on splay faults in the upper crust to explain the geodetic data, but such large slip on splay faults are not required to explain the tsunami waveforms. This may suggest that post(or pre)seismic creep-like slip occurred on the splay faults. On the plate interface, the slip distributions from geodetic and tsunami data agree very well except near Cape Muroto. A large aseismic slip in the plate interface, initially suggested by Kanamori (1972), probably occurred only beneath Cape Muroto. 
Acknowledgments. We thank Masami Okada, Akio Yoshida, Toru Matsuzawa, Kenji Kanjo, and Haruo Horikawa for their helpful discussions and Wayne Thatcher for constructive comments. We also thank Takeshi Sagiya for valuable comments and providing the slip estimates of the 1946 Nankai earthquake using geodetic data. The detailed bathymetry data of which a grid size is $500 \mathrm{~m}$ were provided by Japan Oceanographic Data Center. This work was partially supported by Special Coordination Funds for Promoting Science and Technology by Science and Technology Agency in Japan, "Research on the modeling of earthquake generation mechanism and development of observation technique for mitigating disaster by great earthquake along the Nankai trough".

\section{References}

Aida, I., Numerical experiments for the tsunamis generated off the coast of Nankaido district, Bull. Earthq. Res. Inst., Univ. Tokyo, 56, 713-730, 1981 (in Japanese).

Ando, M., Source mechanisms and tectonic significance of historical earthquakes along the Nankai trough, Japan, Tectonophys., 27, 119-140, 1975.

Ando, M., A fault model of the 1946 Nankaido earthquake derived from tsunami data, Phys. Earth Planet. Inter., 28, 320-336, 1982.

Fitch, T. J. and C. H. Scholz, Mechanism underthrusting in southwest Japan: a model of convergent plate interactions, J. Geophys. Res., 76, 7260 $7292,1971$.

Heki, K., S. Miyazaki, and H. Tsuji, Silent fault slip following an interplate thrust earthquake at the Japan Trench, Nature, 386, 595-598, 1997.

Hyndman, R. D., K. Wang, and M. Yamano, Thermal constraints on the seismogenic portion of the southwestern Japan subduction thrust, J. Geophys. Res., 100, 15373-15392, 1995.

Ishibashi, K. and K. Satake, Problems on forecasting great earthquakes in the subduction zones around Japan by means of paleoseismology, Zisin, J. Seism. Soc. Japan, 50, supplement, 1-21, 1998 (in Japanese).
Ito, K., Seismic activity and tectonics in southwestern Japan, Zisin, J. Seism. Soc. Japan, 43, 555-569, 1990 (in Japanese).

Kanamori, H., Tectonic implications of the 1944 Tonankai and the 1946 Nankaido earthquakes, Phys. Earth Planet. Inter, 5, 129-139, 1972.

Mizoue, M., M. Nakamura, N. Seto, Y. Ishiketa, and T. Yokota, Threelayered distribution of microearthquakes in relation to focal mechanism variation in the Kii peninsula, southwestern Honshu, Japan, Bull. Earthq. Res. Inst., Univ. Tokyo, 58, 287-310, 1983.

Okada, Y., Surface deformation due to shear and tensile faults in a half-space, Bull. Seismol. Soc. Am., 75, 1135-1154, 1985.

Okano, K., S. Kimura, T. Konomi, and M. Nakamura, The focal distribution of earthquakes in Shikoku and its surrounding regions, Zisin, J. Seism. Soc. Japan, 38, 93-103, 1985 (in Japanese).

Sagiya, T. and W. Thatcher, Coseismic slip resolution along a plate boundary megathrust: The Nankai Trough, southwest Japan, J. Geophys. Res., 104, 1111-1129, 1999.

Satake, K., Depth distribution of coseismic slip along the Nankai Trough, Japan, from joint inversion of geodetic and tsunami data, J. Geophys. Res., 98, 4553-4565, 1993.

Satake, K., Linear and nonlinear computations for the 1992 Nicaragua earthquake tsunami, Pure and Applied Geophysics, 144, 455-470, 1995.

Tichelaar, B. W. and L. J. Ruff, How good are our best model? Jackknifing, bootstrapping, and earthquake depth, EOS, 70, 593, 605-606, 1989.

Yabuki, T. and M. Matsuura, Geodetic data inversion using a Bayesian information criterion for spatial distribution of fault slip, Geophys. J. Int., 109, 363-375, 1992.

Yamazaki, F. and T. Ooida, Configuration of subducted Philippine Sea plate beneath the Chubu district, central Japan, Zisin, J. Seism. Soc. Japan, 38, 193-201, 1985 (in Japanese).

Y. Tanioka (e-mail: ytanioka@mri-jma.go.jp) and K. Satake 